\title{
EVALUATION OF CUP PROFILE FOR POSTHARVEST IN COFFEE VARIETY CASTILLO FROM CAUCA DEPARTMENT
}

\author{
A PREPRINT
}

\author{
Andrés Felipe Solis Pino* \\ Grupo IDIS \\ Universidad del Cauca \\ Popayán, Colombia \\ afsolis@unicauca.edu.co \\ Bibiana Montoya \\ Cadenas de Valor \\ Corporación Universitaria Comfacauca \\ Popayán, Colombia \\ bmontoya@unicomfacauca.edu.co
}

\author{
Carlos Andres Anacona Bambague \\ Cadenas de Valor \\ Corporación Universitaria Comfacauca \\ Popayán, Colombia \\ carlosbambague@unicomfacauca.edu.co
}

\author{
Efren Venancio Ramos Cabrera \\ Cadenas de Valor \\ Corporación Universitaria Comfacauca \\ Popayán, Colombia \\ eramos@unicomfacauca.edu.co
}

June 30, 2021

\begin{abstract}
The post-harvest processes of coffee are widely accepted as key factors in determining the quality of the product. In the Cauca department, Southwestern Colombia, this stage is carried out empirically by farmers in the region, using old methods that do not assure consistent quality. This study proposes to determine the best post-harvest temperature and time conditions for coffee produced in the region. For this purpose, we carried the fermentation and honey process out on different coffee samples of the Coffea Arabica species of the Castillo variety. Subsequently, the cup profile quality of the coffee samples was determined by a sensory evaluation by experts. Finally, we applied descriptive statistical techniques to the resulting data and principal component analysis and hierarchical cluster analysis to find similarities between the samples. The results suggest that the honey process gets better evaluations in the cup profile over any condition of temperature and fermentation time.
\end{abstract}

Keywords Fermentation $\cdot$ Honey production $\cdot$ Principal component analysis $\cdot$ Organoleptic characteristics

\section{Introduction}

The Cauca department is one of the primary producers of high-quality coffee in Colombia because of the particularities of its topography and climate, which is why it has become the fourth-largest producer of this bean at the national level [1]. The coffee produced in this region is especially appreciated by baristas and experts, thanks to its strong fragrance and aroma with caramel aspects, besides, when prepared in the cup its acidity is high, its body is medium, and it has a balanced overall impression [2 [3]. Likewise, this product has an important impact on the economy of the Cauca department, since about 95,000 families cultivate 93,000 hectares of Arabica coffee plant, being the indigenous, peasants and Afro-descendant communities the largest producers [4], among the varieties produced, the most outstanding are Castillo, Colombia, Caturra and Borbon [5]. Consequently, this allows inferring the primordial value that coffee has in the region and its inhabitants, so it is of utmost importance to add value to the production of coffee in the department to improve the product.

\footnotetext{
${ }^{*}$ Mechatronics engineer, master student in computer science, with special interest in software engineering and precision agriculture..
} 
In this sense, there have been multiple investigations that seek to improve the production process and the quality of coffee in the cup, in recent times special importance has been given to the so-called semi-washed processed, which is when the fermented coffee is dried without removing the remains of mucilage [6]. This process is fundamental because it is the most complex, laborious, and time-consuming way of producing coffee, but if the activity is successful, it will produce a coffee rich in body and an exceptional flavor [7]. In the research of Ladino-Garzón et al. in [8] where it is proposed to test the cup quality of samples of Caturra, Castillo, and f6 coffee from the south of the department of Huila, for this, it is fermented in water tanks at $0,12,18,18,24$ and 30 hours, subsequently, the quality of the resulting coffee is tested, using the method of the Specialty Coffee Association of America (SCAA, Specialty Coffee Association) to measure the organoleptic characteristics, which are descriptions of the physical characteristics of coffee as perceived by the senses of the experts. Then, an analysis of variance (ANOVA) was executed to determine the effect of time and temperature on fermentation and how it influences the final quality of the product. Finally, they concluded it valued the Castillo and F6 varieties as specialty coffees for all fermentation times, while the fermentation of the Caturra variety at 24 and 30 hours represented a decrease in the last quality of the product. Another research is that of Louzada Pereira et al. [9] the authors state that the production of specialty coffees in the world is increasing because customers demand improvements in the quality and perception of this product. Therefore, they propose a study to test the sensory profile of Conilon coffee at different times (24, 48, 48, 72 , and 96 hours) of fermentation using Saccharomyces cerevisiae to evaluate the modifications in the sensory profile of coffee. Finally, the document concludes that the longer the fermentation time, the greater the increase in the overall score of the coffee. Besides, they suggest that induced fermentations in Robusta species show a promising sensory profile, so they advise using these techniques in real production environments. Another research is that of Peñuela-Martínez et al. [10], who mentioned that coffee mucilage fermentation in the Coffea Arabica species is a process that depends on multiple factors such as microorganisms growing in the environment, climate, maturity, and coffee bean variety. Therefore, the research tests the effect of the different wet fermentation processes and how these influence the quality of coffee, and the concentration of organic acids. The authors use two methodologies, in the first one the pulping time is delayed, while the second method uses a bioreactor to control the Hydrogen Potential (PH) and the temperature fermentation. The results got suggest that the improvement in the coffee's quality was got in those samples in which the fermentation times were short and at low temperatures, thus concluding that it is possible to improve the quality of coffee by introducing changes in the fermentation process in coffee production, thus achieving an improvement in the acidity and fragrance of the final product. Finally, the study by Ribeiro et al. [11], raises the inoculation of two strains of yeast in two varieties of coffee (Ouro Amarelo and Mundo Novo), the results suggest that the catalyst allowed improving the quality of the final product through sensory analysis.

In addition, some studies attempt to improve the final quality of coffee in Cauca and Colombia through the use of technologies. For example, in [12], where the best vegetation indexes for measuring chlorophyll in the Castillo variety are determined. Besides in [13], they try to genetically improve the coffee plant, or even in [14], new varieties with better characteristics are obtained. Although different research tries to improve the coffee produced in the Cauca department, specifically in the Castillo variety, there is no evidence of studies that allow determining the ideal fermentation conditions (time and temperature) to improve the final product, so there is a lack of knowledge in the post-production processes of this fundamental fruit for the region. Likewise, many producers in the department of Cauca associate empirical practices in the processing of coffee, determining the time and temperature of the aerobic fermentation cycle based on the perceptions of touch, sensations, and sounds in the beans [15], generating that a homogeneous quality is not guaranteed in its production, causing poorly processed coffee harvests and high production costs [16]. This represents a clear production disadvantage compared to other regions, since market competitiveness privileges quality over other conditions, preferring the added value determined by the sensory properties that describe the specialty in the cup profile [17].

Based on the above and having as its main concern to contribute to the improvement of the Cauca coffee production process, this research aims to determine the best conditions (temperature and fermentation time) in post-production for the coffee of the region, using a sensory analysis to determine the cup quality in coffee.

\section{Material and Methods}

Twenty-eight coffee samples of the Coffea Arabica species of the Castillo variety in a state of complete ripening (divided into two cupping processes) were tested. The beans came from lot number three of the hacienda "Los Naranjos" of the Parque Tecnológico de innovación del Café (Tecnicafé), which is in the municipality of Cajibío in the Cauca department, with geographical coordinates $2^{\circ} 35^{\prime} 11.6^{\prime \prime} \mathrm{N}$ y $76^{\circ} 33^{\prime} 11.2^{\prime \prime} \mathrm{W}$, at an approximate altitude of 1862 height above sea level and an estimated ambient temperature of 12 to $18^{\circ}$ Celsius [18]. The harvested crop is of agrochemical production, under the shade with a staggering planting system, with a distance of 1.5 meters between the coffee trees, the approximate age of the trees is four and a half years since they are transplanted to their final site in the field. This 
A PREPRINT - JUNE 30, 2021

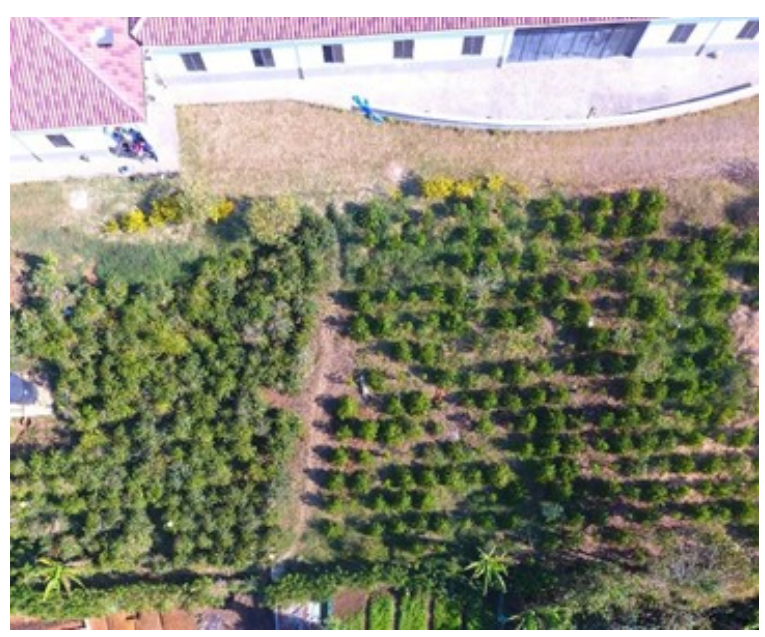

(a) Crop where the coffee samples were collected.

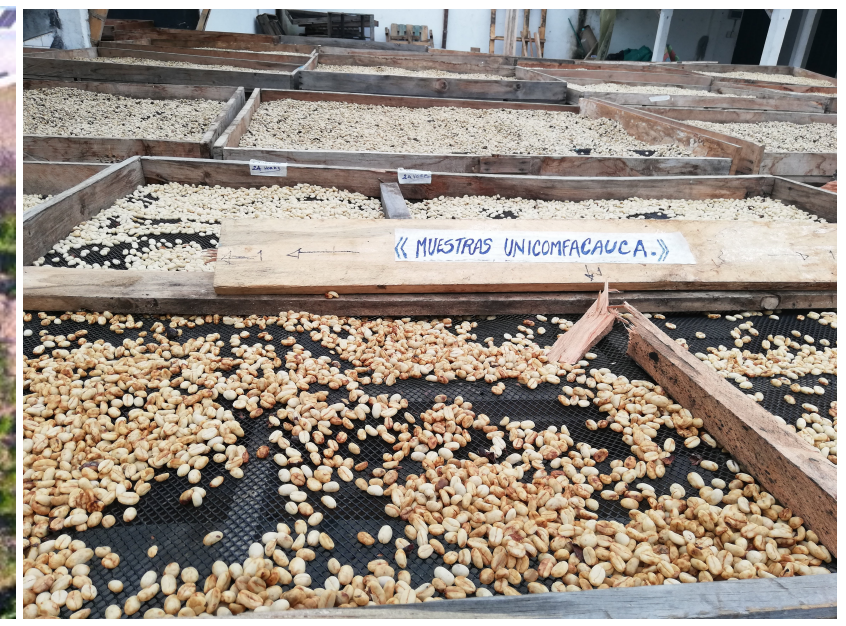

(b) Post-harvest coffee for fermentation tests and honey processing.

Figure 1: Coffee produced in the Cauca department of the species Coffea arabica.

coffee production lot has been given to the Corporación Universitaria Comfacauca, as a control lot to carry out diverse scientific research to improve coffee production in the Cauca department (Figure 1a).

Subsequently, $50 \mathrm{~kg}$ of cherry coffee were taken and transported in refrigerated compartments to the processing plant in Supracafé [19], and processed in a pulper (Figure 1b). They underwent a semi-washed process that produced Baba coffee and stored it in containers at different temperatures (see Table 1 , for identification of samples). The first sample group was stored at "cold temperature" with values between 10 and $16{ }^{\circ} \mathrm{C}$, the second sample group at "ambient temperature" with values between 17 and $23^{\circ} \mathrm{C}$, and finally, the third group at "hot temperature" with values between 24 and $29^{\circ} \mathrm{C}$. The above temperature range is because the aim was to simulate the different temperature conditions of the thermal floors of the Cauca department. We subjected these specimens to aerobic fermentation by taking samples in triplicate at different times $(6,12,18$, and 24 hours). Then, the mucilage was then manually removed with clean water, ensuring the homogeneity of all samples. The moisture loss process was carried out by solar drying in the Supracafé processing station with a humidity between 10 and $12 \%$, to fix the microbial activity [20]. In parallel, we took samples to perform the coffee processing through the honey process (which is a method in which fresh coffee cherries are pulped, but left to dry without washing, leaving a minimum of mucilage around the bean [21]) to determine its cup profile and compare it with the semi-washed process, since other research has shown that this process contributes the final quality of the coffee. Subsequently, the coffee was threshed and classified by size in 14 mesh, followed by the analysis of physical coffee bean defects based on the recommendation by Federación Nacional de Cafeteros [17]. Two certified expert coffee tasters evaluated the quality of the coffee (determining the organoleptic characteristics) produced following the method established by the SCAA [22]. Besides, they calculated the rating values under the ISO 17025 procedure of Almacafé. Likewise, the response variables of this study are the organoleptic characteristics established for each of the coffee samples under different post-production conditions.

Finally, to determine the relationship between the sensory evaluations of the cup profiles, Principal Component Analysis (PCA) and hierarchical clustering were used to determine the similarity between the samples.

\section{Results and Discussion}

In this section, the main results obtained during the research related to the cup profile scores are presented and then analyzed using descriptive and inferential statistical techniques.

\subsection{Results of the cup profiles obtained}

Based on the evaluation of the cup profile carried out in each of the cupping processes with different benefits (honey process and fermentation process), the results showed that all the samples analyzed obtained a score between 82 and 85 points, which translates into "very good" coffees by the SCAA [23]. The above allows determining that beyond the time and temperature scenarios to which the coffees were subjected, these are differentiated products by characteristics 
A PREPRINT - JUNE 30, 2021

Table 1: Acronyms of the samples used in the study

\begin{tabular}{ll}
\hline \multicolumn{2}{c}{ Acronyms for samples used } \\
\hline Name & Acronym \\
\hline Cold temperature sample at 6 hours of fermentation & $6 \mathrm{~F}$ \\
Cold temperature sample at 12 hours of fermentation & $12 \mathrm{~F}$ \\
Cold temperature sample at 18 hours of fermentation & $18 \mathrm{~F}$ \\
Cold temperature sample at 24 hours of fermentation & $24 \mathrm{~F}$ \\
Ambient temperature sample at 6 hours of fermentation & $6 \mathrm{~A}$ \\
Ambient temperature sample at 12 hours of fermentation & $12 \mathrm{~A}$ \\
Ambient temperature sample at 18 hours of fermentation & $18 \mathrm{~A}$ \\
Ambient temperature sample at 24 hours of fermentation & $24 \mathrm{~A}$ \\
Hot temperature sample at 6 hours of fermentation & $6 \mathrm{C}$ \\
Hot temperature sample at 12 hours of fermentation & 12C \\
Hot temperature sample at 18 hours of fermentation & $18 \mathrm{C}$ \\
Hot temperature sample at 24 hours of fermentation & 24C \\
Sample honey washing process & HL \\
Sample unwashed honey process & HSL \\
Café denominación de origen Cauca & D.O.C \\
\hline
\end{tabular}

of origin, preparation, and sustainability in their production, reaffirming the quality coffee produced in the Cauca department [24].

Figure 2 shows the different cup profiles for the honey and fermentation process. The samples subjected to the honey process presented better results even above any specimen subjected to fermentation process under different conditions, probably because in the absence of decomposing microorganisms, the sugars and other enzymes remain present in the grain, which results in sweeter coffees and with a drier aftertaste and therefore better valued [25]. The green coffee produced after honey processing gets a greater mixture of tannins, floral notes, and impregnated aromas that translate into better flavors when preparing the coffee drinks, so it is widely accepted that the honey process should be used when seeking to find a balance of flavors, highlighting the best of washed coffee and natural coffee. The above results coincide with what has been found by other research, such as that of Burbano et al. in [26] and Boyacá Vásquez in [27], where they have tried to find which are the best processes to optimize the cup profiles of the Castillo variety in both the Huila and Boyacá departments, the inquiries yielded as the main result that the honey process offers the best organoleptic characteristics above the fermentation processes. According to the previous results, the Castillo variety produced in the Cauca department gets better cup profiles through the honey process, therefore it is important to carry out socialization campaigns by the competent authorities to disseminate the honey process as a viable post-processing alternative, and thus obtain differentiated and better-paid coffees.

The fermentation process plays an essential role in determining the quality of coffee in the cup. It is a natural process that occurs when the beans are harvested, and it groups the sugars and water. The fermentation process can improve or detract from the quality of a coffee, but it is not the only determinant of flavor, since elements such as ambient temperature, ripening, and humidity of the fruit also play an active role in this decomposition process, so it is not a linear process [28]. Now, the results for fermentation at cold temperatures allowed determining that there is a progressive increase in the score obtained by the specimens as the degradation period passes, which is logical and confirms what has been shown by other research [29,30]. The reason for this is that the microorganisms responsible for fermentation perform the decomposition more slowly [31] so that substances such as sugar, ethanol, acetic acid, lactic acid, and carbon dioxide take a longer time to be liberated from the coffee bean [32]. Specifically, samples 24F, 6A, and 12A were distinguished for being coffees with pleasant and delicate flavors, constituting the specimens with the best evaluation of the cup profile in the fermentation process. Specifically, specimen 24A obtained a decrease in the cup profile score with slightly vinegary and metallic flavors, which allows inferring that after the 18 hours of fermentation at ambient temperatures the cup quality coffee decreases, the above is in line with what was expressed by Ladino-Garzón et al. in [8], where it is appreciated that the Castillo variety coffee produced in the department of Huila presents a decrease in quality after 24 hours of fermentation with an approximate temperature of $22{ }^{\circ} \mathrm{C}$, the same as for coffee produced in Cauca at ambient temperature. The above allows us to infer that this is the range of temperatures at which coffee growers in the region should process their products, and therefore, in the Cauca department in zones with temperatures between 17 and $23{ }^{\circ} \mathrm{C}$ the semi-washed fermentation should be carried out with a maximum limit of 18 hours, to avoid the loss of differential characteristics in the cup profile. Finally, for the hot temperatures, it was found that the results are on average lower than for the other two sample groups, influenced by sample $12 \mathrm{C}$, which in the two cupping processes 


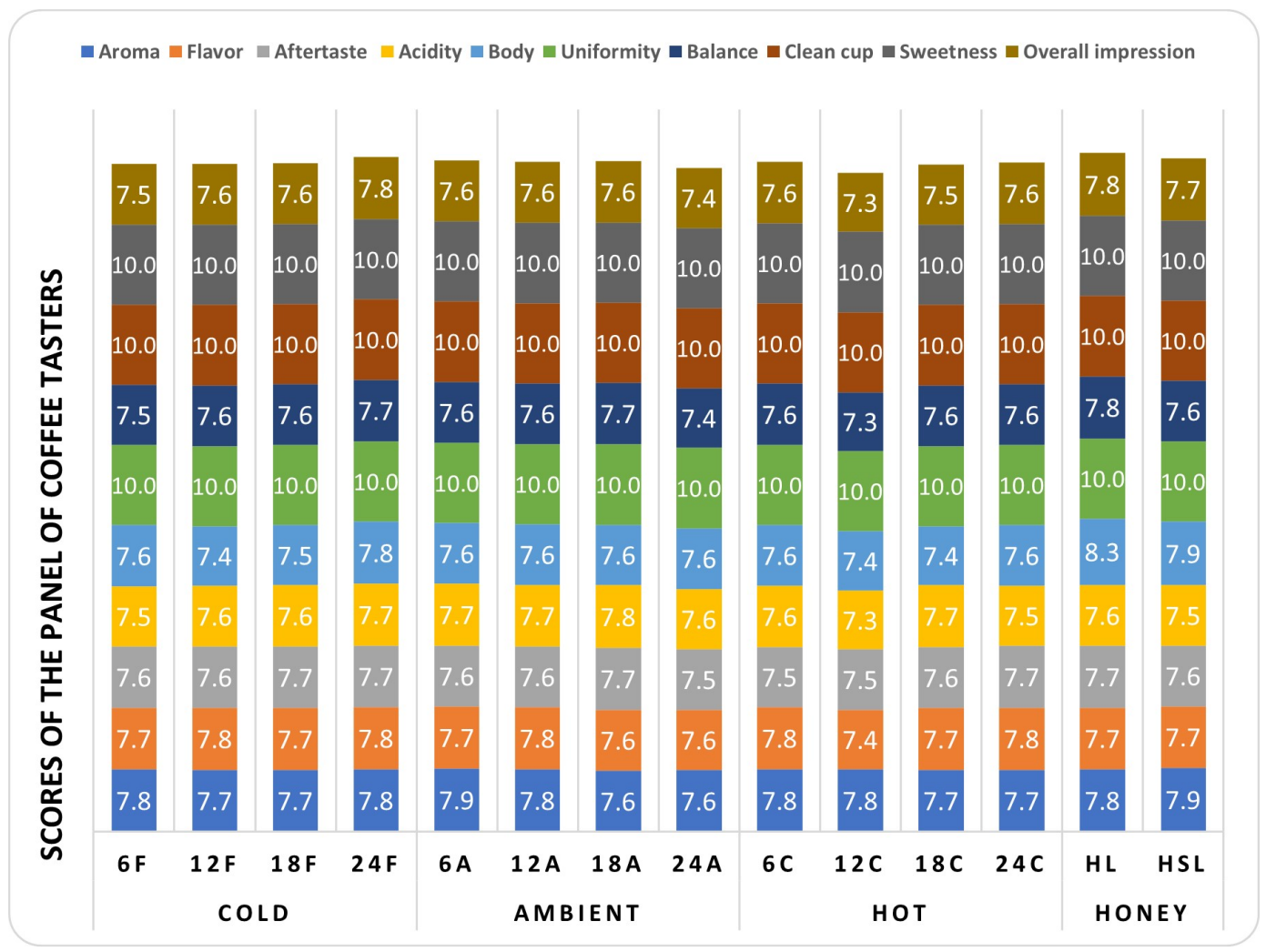

Figure 2: Average cup profile results performed using the SCAA protocol.

performed showed low values because the acidity and balance in these samples had low scores concerning the others, giving citric flavors with hints of bitterness.

\subsection{Principal component analysis on the evaluated samples}

A principal component analysis was carried out for the ten organoleptic characteristics measured in the coffee samples at different temperature and time conditions, we determined two principal components that present an eigenvalue greater than 1 and that together explain approximately $81 \%$ of the total accumulated variance, the selection of these components is based on the Kaiser criterion [33]. Specifically, we observed that the organoleptic characteristics with the greatest influence on CP1 are body, acidity, and overall impression with communality values greater than 0.86 , while aftertaste and aroma are poorly representative with communalities less than 0.68 .

Figure 3 shows that there are three main groups of samples. The first conglomerate is formed by all the samples that were subjected to fermentation except for sample 24F, suggesting that these samples are similar in their organoleptic characteristics beyond the opposite conditions to which they were subjected, in addition, these samples present low results in the cup profile compared to other groups. The second conglomerate comprises the $24 \mathrm{~F}$ samples from the fermentation process and the washed and unwashed samples from the honey process; the samples in this group are the ones that present the best organoleptic characteristics, with special flavors with hints of slightly intense chocolate, red fruits, and a certain fruity acidity. Finally, the denomination of origin café del Cauca profile does not show similarity with any of the samples studied, this may be because the D.O.C. scores are an average of multiple samples analyzed from the entire Cauca department, so it is not a measure for coffee produced in a single place. Therefore, it can allude that the denomination of origin should not be a comparative measure concerning the cup profile evaluations but should be a guide to guarantee a differentiated product according to the conditions that the geographical region where it was grown may have.

Figure 4 shows the body, overall impression, and aftertaste are related, so if someone scored one of these properties the others tend to obtain high scores or inversely. A similar case occurs with flavor, balance, aroma, and acidity. The next figure also shows that the organoleptic characteristics have varied characteristics and are not subordinated to one characteristic property, which speaks of the diversity of the samples studied. 


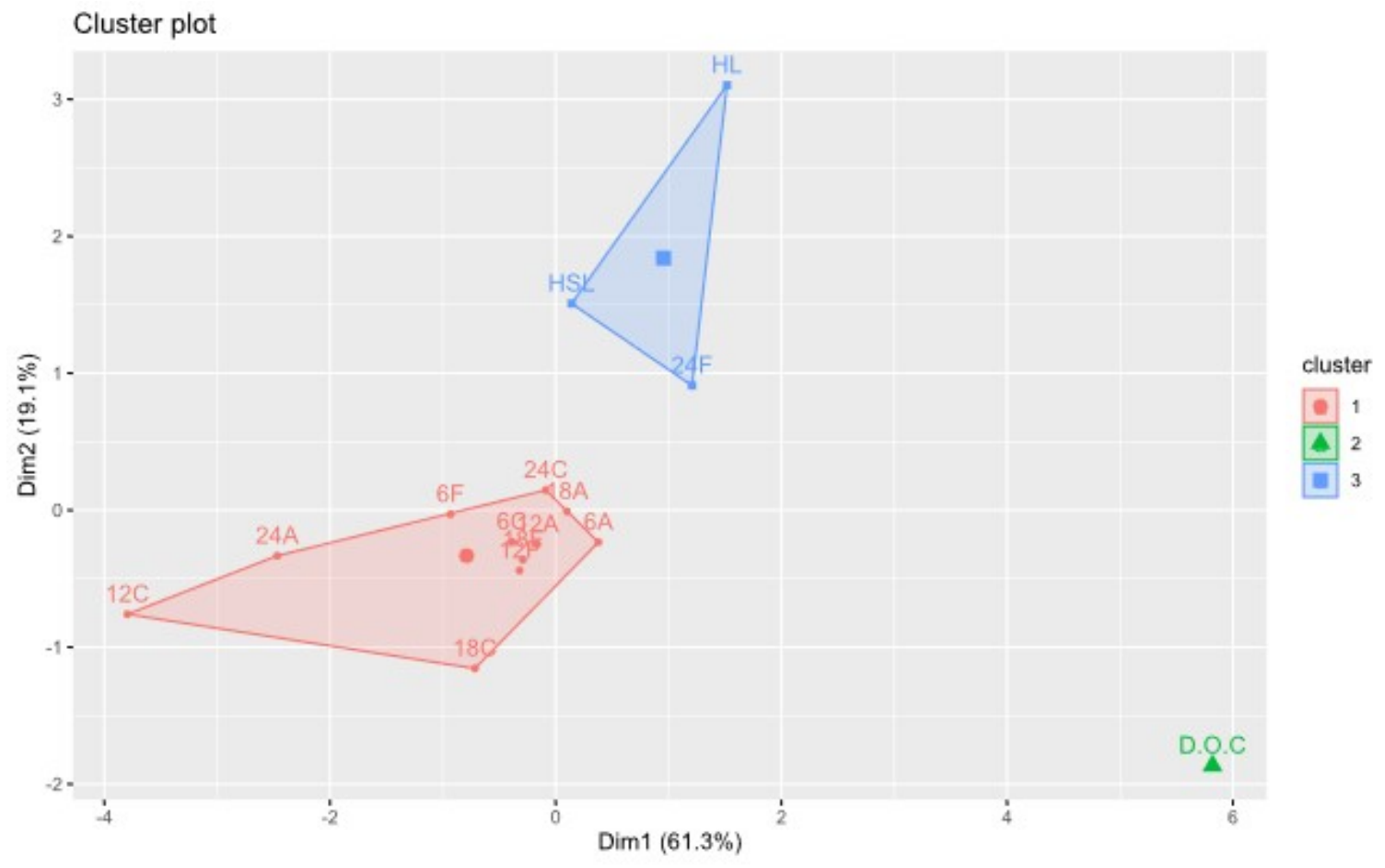

Figure 3: Grouping of samples according to their level of similarity for PCA analysis.

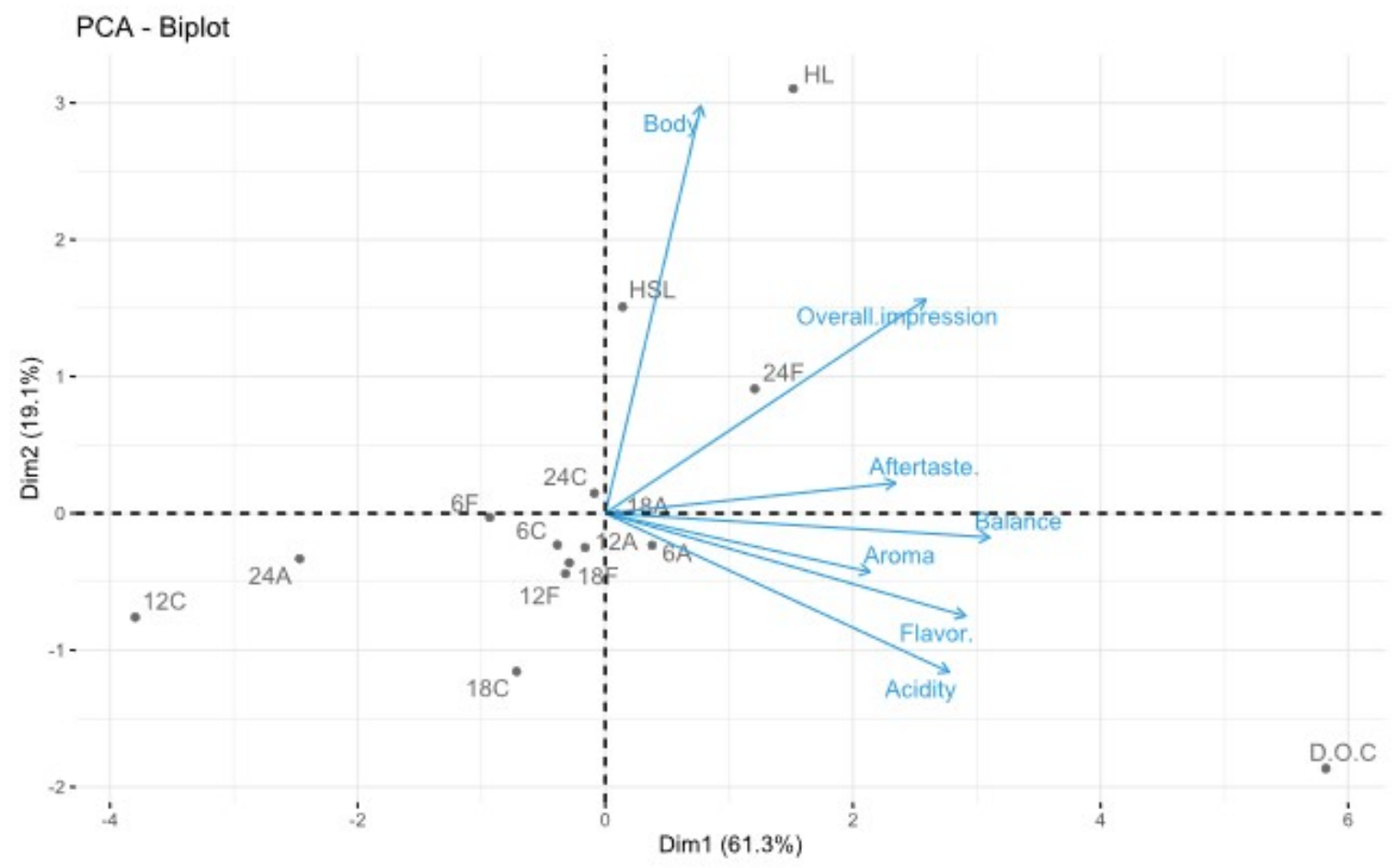

Figure 4: Biplot graphic of the PCA analysis for individuals and organoleptic properties evaluated according to cup profile. 
Another analysis that allows us to perform the PCA is to determine under what circumstances the individuals studied are similar. Here, the individuals of cluster two related by organoleptic characteristics such as body, cup scores, and aftertaste, so it can be affirmed that the coffee processed under the conditions of these samples get similar characteristics in the mentioned organoleptic characteristics, which translates into the fact that these types of samples get high scores in these properties. Specifically, the samples submitted to honey processing are related to a high score in the coffee body, which shows that when these samples are evaluated, this property stands out above others and is characteristic of this type of samples, while for properties such as aroma and acidity there is certain independence so that if one wants to improve the general qualification in the cup, processes that enhance these properties should be carried out.

However, the samples in cluster 1 are not significantly related by any specific property, so the coffees produced under these conditions do not have characteristics that stand out from the others. In addition, it was found that samples $12 \mathrm{C}$, $18 \mathrm{C}$, and 24A are indirect to the aftertaste and balance properties, so the low cup profile scores for these samples are because high scores are rarely obtained for these properties. Likewise, with group 1 individuals, it is noted that to improve their average cup score, it should emphasize organoleptic characteristics, such as flavor, aftertaste, aroma, and acidity.

\subsection{Hierarchical clustering}

We performed a hierarchical clustering analysis to identify the similarity between variables and individuals using the complete linkage clustering method and Euclidean distance, based on the AGNES clustering method. Previously, we validated that there were no missing data and standardized the information to ensure its uniformity.

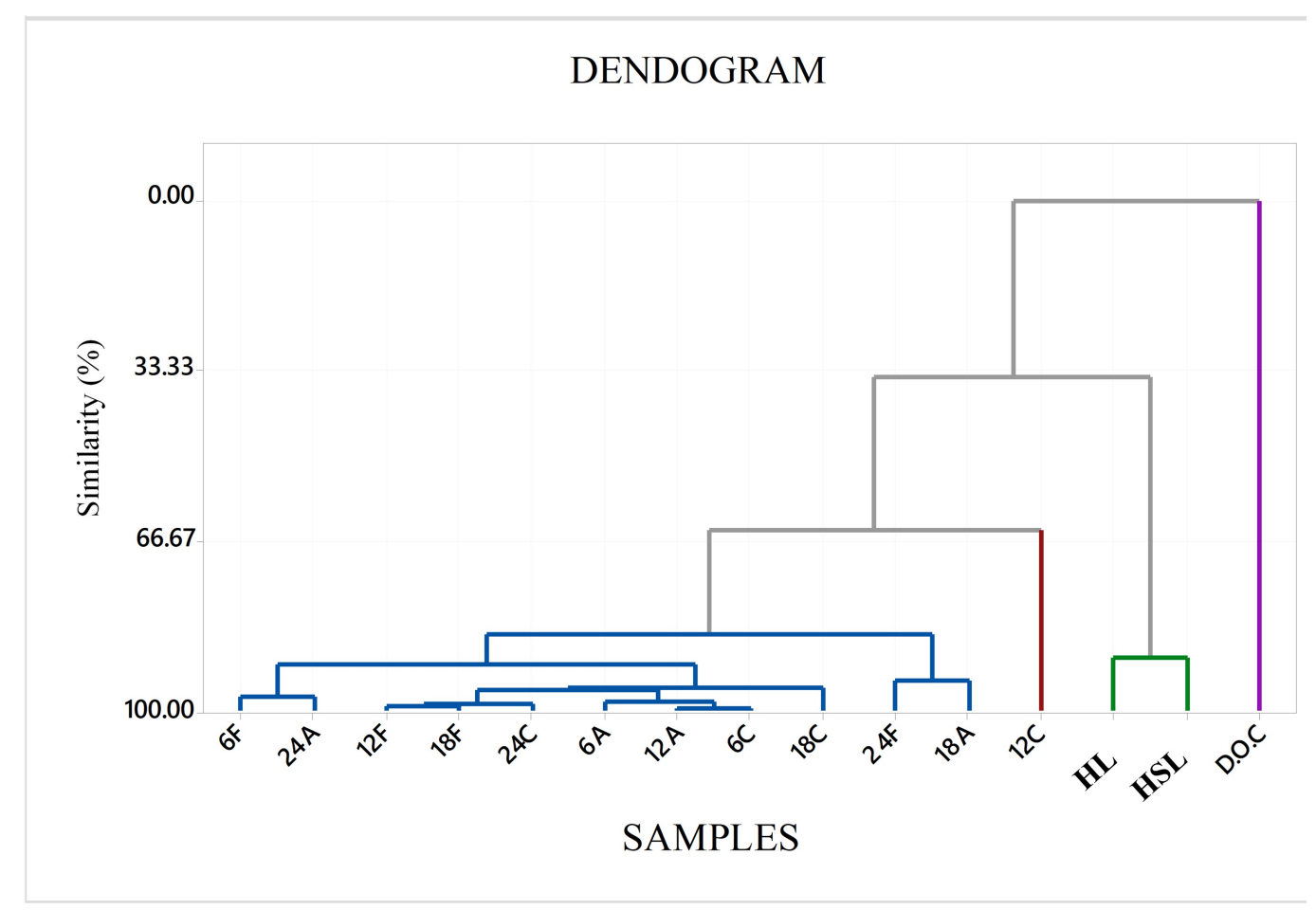

Figure 5: Dendrogram resulting from the hierarchical analysis performed for the samples evaluated by cup profiles.

Figure 5 shows the dendrogram resulting from the hierarchical analysis performed, which allows us to get a series of important premises about the samples subjected to different processes and post-harvest conditions. Specifically, the hierarchical analysis yielded results similar to the PCA, where it was found that the fermented samples (except sample 12C) have an approximate similarity of $85 \%$, which shows that the time and temperature conditions during the fermentation process influence to a lesser degree, while the honey process samples their similarity is approximately $39 \%$, which allows inferring that the type of post-harvest processing influences the quality of the cup profile in the Castillo variety produced in the Cauca department. Finally, it was found that the fermented samples and honey process samples do not have a relationship with the results of the D.O.C. profile. 
A PREPRINT - JUNE 30, 2021

We relate the groups formed in the hierarchical analysis to the clusters found in the component analysis, which reaffirm what we mentioned in the previous section. Specifically, the dendrogram reaffirms that the best cup scores for the fermented samples (24F, 6A, and 12A) are similar, with a level of similarity of $92 \%$, which was also observable in the PCA evaluation where these samples are found at short distances. According to the above and considering the PCA analysis and the results of the cup profile, it can be inferred that the ideal conditions for fermenting coffee produced in Cauca of the Castillo variety are in cold temperatures at 24 hours and in ambient temperatures between 6 and 12 hours. Likewise, it can be noted that sample $12 \mathrm{C}$ has an approximate similarity of $80 \%$ with the rest of the fermented samples. This affirms what we expressed for the organoleptic characteristics of balance and acidity, which for these samples negatively affect the scores in the cup profile.

\section{Conclusions}

This paper presents an investigation that attempts to determine the ideal post-production conditions for coffee produced in the Cauca department, using the SCAA protocol to determine the cup quality of the samples analyzed. Besides, descriptive and inferential statistical techniques (component analysis and group analysis) are used to determine the best post-production conditions.

The results suggest that the honey process is the method that got the best results in cup profile, so if a competitive differentiated coffee is to be obtained, the socialization of this post-production method could be carried out among the producers and growers of the Cauca department. In the fermentation process, it can be mentioned that the ideal temperature conditions are between 10 and $23{ }^{\circ} \mathrm{C}$ to get the best organoleptic characteristics in the region's coffee. Besides, while it is true that the post-harvest processes influence the results of the cup profiles, it also plays a fundamental role where the fruit is grown, so that the post-harvest processes allow differentiating the coffees obtained, but they are not the only factor that influences the quality coffee.

Finally, one of the major future works could be to systematize the post-production process in small coffee producers to get differentiated coffees with a representative flavor to promote this sector in the region.

\section{Acknowledgement}

We thank the Corporación Universitaria Comfacauca for the technical and technological support received in the research, as well as Tecnicafé for the intellectual and methodological support.

\section{References}

[1] Anderson Arenas-Clavijo and Inge Armbrecht. Gremios y diversidad de hormigas (Hymenoptera: Formicidae) en tres usos del suelo de un paisaje cafetero del Cauca-Colombia. Revista de BiologÃ $\backslash$-a Tropical, 66:48 - 57, 2018. Publisher: scielo.

[2] Diego Andrés Campo Ceballos and Carlos Alberto Gaviria López. Optimización de las condiciones de tiempo y temperatura en el proceso de tostado de café del cauca, teniendo en cuenta la percepción del consumidor. In Encuentro Internacional de Educación en Ingeniería 2019, Cartagena, Colombia, 2019.

[3] Andrés Villegas Hincapié, Huver Posada, Carolina Pérez Henao, Claudia Arboleda, and Luis Samper. Otros retos de la caficultura. Regionalización de la calidad del café de Colombia, Denominaciones de origen como estrategia de valor agregado. pages $181-208.2013$.

[4] Kevin Alexis Gómez Burbano. Diseño industrial del proceso de fabricación de madera aglomerada con base en los residuos de la producción de café en el municipio de Cajibío, Cauca. Encuentro Internacional de Educación en Ingeniería, August 2020.

[5] Ana Diaz Bohorquez, Nicholas Bayly, Jorge Botero, and Camila Gómez. Aves migratorias en agroecosistemas del norte de Latinoamérica, con énfasis en Colombia. Ornitologia Colombiana, 14:3-23, 2014.

[6] Giselle S. Duarte, Antônio A. Pereira, and Adriana Farah. Chlorogenic acids and other relevant compounds in Brazilian coffees processed by semi-dry and wet post-harvesting methods. Food Chemistry, 118(3):851-855, February 2010.

[7] Palmiro Poltronieri and Franca Rossi. Challenges in Specialty Coffee Processing and Quality Assurance. Challenges, 7(2):19, October 2016. 
[8] Wilmer Ladino-Garzón, Erika T Cortés-Macías, Nelson Gutiérrez-Guzmán, and Claudia M Amorocho-Cruz. Calidad de taza de café (Coffea arabica L.) procesado en fermentación semi-seca. Agronomía Colombiana, 34(1):S281-S283, 2016.

[9] Lucas Louzada Pereira, Aldemar Polonini Moreli, Dério Brioschi Júnior, Luiz Henrique Bozzi Pimenta de Sousa, João Paulo Pereira Marcate, Gustavo Falquetto de Oliveira, Danieli Grancieri Debona, and Rogério Carvalho Guarçoni. CONSTRUÇÃO DE PERFIL SENSORIAL PARA O CAFÉ CONILON FERMENTADO. Revista Ifes Ciência, 5(2):242-252, 2019.

[10] Aida Esther Peñuela-Martínez, Arley David Zapata-Zapata, and Diego Luis Durango-Restrepo. Performance of different fermentation methods and the effect on coffee quality (Coffea arabica L.). Coffee Science - ISSN 1984-3909, 13(4):465 - 476, December 2018.

[11] Luciana Silva Ribeiro, Diego Egídio Ribeiro, Suzana Reis Evangelista, Maria Gabriela da Cruz Pedrozo Miguel, Ana Carla Marques Pinheiro, Flávio Meira Borém, and Rosane Freitas Schwan. Controlled fermentation of semi-dry coffee (Coffea arabica) using starter cultures: A sensory perspective. LWT - Food Science and Technology, 82:32-38, September 2017.

[12] Andrés Felipe Solis. Correlación del contenido de clorofila foliar de la especie Coffea arabica con índices espectrales en imágenes. Biotecnología en el Sector Agropecuario y Agroindustrial, pages 1-15, January 2021.

[13] J Castillo. Mejoramiento genético del café en Colombia. 50 años de Cenicafé. Conferencias Conmemorativas, 1990.

[14] Jaime Castillo Zapata and Germán Moreno Ruíz. Selección de cruzamientos derivados del Híbrido de Timor en la obtención de variedades mejoradas de café para Colombia. Cenicafé (Colombia) v. 32 (2) p. 37-53, 1981.

[15] SM Marín, J Arcila, EC Montoya, and CE Oliveros. Relación entre el estado de madurez del fruto del café y las características de beneficio rendimiento y calidad de la bebida. Cenicafé, 54(4):297-315, 2004.

[16] Canet Brenes, Armandocoord García, and others. Guía técnica para el beneficiado de café protegido bajo una indicación geográfica ó denominación de origen. Technical report, 2010.

[17] Alejandro Ospina Marulanda. La industria de los cafés de especialidad. Relación entre certificaciones de calidad o especialidad, y los ingresos de los caficultores en Colombia. 1989-2015. PhD Thesis, Universidad del Rosario, 2017.

[18] Zulma Katerine Ordoñez Fernández and Bibiana Patricia Montoya Bonilla. Evaluación agronómica de Coffea Arábica variedad castillo y caturra en dos sistemas de producción (sol y sombra); en la hacienda los naranjos, vereda la Venta (Cajibio-Cauca). ACCB, 1(29):Artículo Páginas 58-66, October 2017.

[19] David Camilo Corrales, Iván Darío López, Felipe Campo, Silvio Andrés Ordoñez, Juan Carlos Corrales, Apolinar Figueroa Casas, and Carlos León Roa. Plataforma para el seguimiento de variables meteorológicas y ambientales para el sector agropecuario. In en VII Congreso Ibérico de AgroIngeniería y Ciencias Hortícolas, Madrid, Madrid, Spain, 2013.

[20] Liang Wei Lee, Mun Wai Cheong, Philip Curran, Bin Yu, and Shao Quan Liu. Coffee fermentation and flavor An intricate and delicate relationship. Food Chemistry, 185:182-191, October 2015.

[21] D A Priyadi, G S Prayogo, and K M Nur. Smallholder farmers' perceptions of coffee bean processing using the honey method. IOP Conference Series: Earth and Environmental Science, 672(1):012025, mar 2021.

[22] Gilberto Vinícius de Melo Pereira, Ensei Neto, Vanete Thomaz Soccol, Adriane Bianchi Pedroni Medeiros, Adenise Lorenci Woiciechowski, and Carlos Ricardo Soccol. Conducting starter culture-controlled fermentations of coffee beans during on-farm wet processing: Growth, metabolic analyses and sensorial effects. Food Research International, 75:348-356, September 2015.

[23] Specialty Coffee Association of America. SCAA protocols-cupping specialty coffee. 2015.

[24] GI Puerta. Especificaciones de origen y buena calidad del café de Colombia. Technical report, Centro Nacional de Investigaciones de Café (Cenicafé), 2013.

[25] Víctor Manuel Martínez, Iván Darío Aristizábal, and Edilson León Moreno. Evaluation of the composition effect of harvested coffee in the organoleptic properties of coffee drink. Vitae, 24(1):47 - 58, 2017. Publisher: scieloco.

[26] Mileyi Burbano Jurado and Wilmar Iván Cabrera Artunduaga. Conocer el perfil de taza generado mediante la implementación de los métodos de cafés naturales, honey y cafés lavados con la variedad castillo general en los asociados a la Cooperativa Departamental de Caficultores del Huila-Cadefihuila del municipio de Acevedo-Huila. $\mathrm{PhD}$ thesis, Universidad Nacional Abierta y a Distancia de Colombia (UNAD), Huila, Colombia, 2018. 
[27] Licett Andrea Boyacá Vásquez. Estudio exploratorio de la obtención de café verde mediante beneficio Honey y la determinación de su calidad en taza. Master's thesis, Universidad Nacional de Colombia - Sede Bogotá, Bogotá Colombia, 2018.

[28] GI Puerta. Calidad física del café de varias regiones de Colombia según altitud suelos y buenas prácticas de beneficio. Cenicafé, 67(1):7-40, 2016.

[29] Kênia Barbosa do Carmo, Jéssica Conceição Barbosa do Carmo, Marcelo Rodrigo Krause, and Guilherme Peterle. Sensory and physiological quality of arabic coffee under different fermentation times. Bioscience Journal, 36(2), 2020.

[30] Nataly Peña Gómez, Oscar Barrera Bermeo, and Nelson Gutiérrez Guzmán. Efectos del tiempo de fermentación sobre la calidad en taza del café (coffea arabica). Ingeniería y Región, 10:111-116, December 2013.

[31] Sylvie Avallone, Bernard Guyot, Jean-Marc Brillouet, Eugenia Olguin, and Joseph-Pierre Guiraud. Microbiological and Biochemical Study of Coffee Fermentation. Current Microbiology, 42(4):252-256, April 2001.

[32] GI Puerta. Factores procesos y controles en la fermentación del café. Technical report, Centro Nacional de Investigaciones de Café (Cenicafé), 2013.

[33] Henry F. Kaiser. Coefficient Alpha for a Principal Component and the Kaiser-Guttman Rule. Psychological Reports, 68(3):855-858, 1991. _eprint: https://doi.org/10.2466/pr0.1991.68.3.855. 